\title{
KARAKTERISTIK INGOT PADUAN U-Zr-Nb PASCA PROSES QUENCHING
}

\author{
Masrukan, Jan Setiawan \\ Pusat Teknologi Bahan Bakar Nuklir-BATAN \\ Kawasan Puspiptek, Serpong, Tangerang Selatan, 15314 \\ e-mail : masrukan2006@yahoo.com
}

(Naskah diterima: 12-05-2017, Naskah direvisi: 13-06-2017, Naskah disetujui: 28-06-2017)

\begin{abstract}
ABSTRAK
KARAKTERISTIK INGOT PADUAN U-Zr-Nb PASCA PROSES QUENCHING. Telah dilakukan percobaan perlakuan panas (quenching) paduan U-Zr-Nb yang bervariasi komposisi $\mathrm{Nb}$. Ingot paduan U-Zr-Nb dengan komposisi $\mathrm{Nb}$ yang bervariasi yakni $1 \%, 4 \%$ dan $7 \%$ dan komposisi $\mathrm{Zr}$ tetap $10 \%$ dibuat melalui peleburan logam $\mathrm{U}, \mathrm{Zr}$ dan $\mathrm{Nb}$ di dalam tungku busur listrik. Percobaan perlakuan panas (quenching) dimaksudkan untuk mengubah fasa aU yang tidak stabil menjadi fasa $\gamma \mathrm{U}$ yang stabil. Pada percobaan quenching, ingot paduan $\mathrm{U}-10 \mathrm{Zr}-1 \mathrm{Nb}, \mathrm{U}-10 \mathrm{Zr}-4 \mathrm{Nb}$, $\mathrm{U}-10 \mathrm{Zr}-7 \mathrm{Nb}$ dimasukkan ke dalam ampul yang terbuat dari pelat baja kemudian dimasukkan ke dalam tungku pemanasan dan dipanaskan pada temperatur $900{ }^{\circ} \mathrm{C}$ serta ditahan selama 2 jam untuk selanjutnya didinginkan dengan cepat di dalam air. Setelah diquenching dikenai pengujian fasa dan pemeriksaan mikrostruktur. Pengujian fasa dilakukan menggunakan difraksi sinar- $X$ (XRD) yang datanya diolah menggunakan software High Score, sedangkan pemeriksaan mikrostruktur menggunakan mikroskop optik. Hasil pengujian dengan XRD menunjukkan bahwa paduan $\mathrm{U}-10 \mathrm{Zr}-1 \mathrm{Nb}$ sebelum diquenching terdiri dari fasa $\mathrm{aU}$ dan paduan $\mathrm{U}-10 \mathrm{Zr}-4 \mathrm{Nb}$ terdiri dari fasa $\alpha U$ sebesar $23,1504 \%$ dan fasa $\gamma \mathrm{U}$ sebesar $76,8495 \%$, sedangkan pada $\mathrm{U}-10 \mathrm{Zr}-7 \mathrm{Nb}$ terdiri dari fasa aU sebesar $34,1873 \%$ dan fasa $\gamma U$ sebesar $65,8127 \%$. Paduan $U-10 Z r-1 \mathrm{Nb}$ setelah diquenching terdiri fasa $\alpha \mathrm{U}$, sedangkan paduan $\mathrm{U}-10 \mathrm{Zr}-4 \mathrm{Nb}$ terdiri dari fasa aU sebesar $44,6711 \%$ dan fasa $\gamma \mathrm{U}$ sebesar $55,3289 \%$, paduan $\mathrm{U}-10 \mathrm{Zr}-7 \mathrm{Nb}$ terdiri dari fasa aU sebesar $17,9918 \%$ dan fasa $\gamma \mathrm{U}$ sebesar $82,0082 \%$. Hasil analisis densitas teoritis terhadap fasa yang terbentuk pada paduan $\mathrm{U}-10 \mathrm{Zr}-1 \mathrm{Nb}, \mathrm{U}-10 \mathrm{Zr}-4 \mathrm{Nb}, \mathrm{U}-10 \mathrm{Zr}-7 \mathrm{Nb}$ baik sebelum maupun setelah diquenching diperoleh ingot paduan U-10Zr-1 Nb, U-10Zr-4Nb, U-10Zr-7Nb menunjukkan bahwa densitas fasa $\alpha U$ dan fasa $\gamma U$ mengalami penurunan sedikit apabila kandungan $\mathrm{Nb}$ semakin rendah. Sementara itu, hasil pemeriksaan mikrostruktur menunjukkan bahwa pada kandungan $\mathrm{Zr}$ yang semakin tinggi $(7 \% \mathrm{Nb})$ terbentuk butir lebih kecil (halus) setelah mengalami quenching. Dapat disimpulkan bahwa proses quenching paduan U-10Zr-1 Nb, U-10Zr-4Nb, dan U-10Zr-7Nb akan mengubah fasa dari fasa $\alpha \mathrm{U}$ menjadi fasa $\gamma \mathrm{U}$ dan mikrostruktur yang terbentuk. Perubahan mikrostruktur menunjukkan bahwa kandungan $\mathrm{Nb}$ yang semakin tinggi maka butir yang terbentuk menjadi semakin halus.
\end{abstract}

Kata kunci: mikrostruktur, U-Zr-Nb, quenching, fasa, densitas. 


\section{ABSTRACT}

INGOT CHARACTERISTIC OF U-Zr-Nb ALLOYS POST QUENCHING PROCESS. The U-Zr-Nb heat-quenching experiment has been subjected to various $\mathrm{Nb}$ compositions. Ingots of $\mathrm{U}$-Zr-Nb alloys with varying $\mathrm{Nb}$ compositions are $1 \%, 4 \%$ and $7 \%$ and a fixed $10 \% \mathrm{Zr}$ composition is made by melting $U, \mathrm{Zr}$ and $\mathrm{Nb}$ metals in an electric arc furnace. The quenching experiment is intended to convert an unstable phase $\alpha U$ into stable $\gamma U$ phase. Quenching experiment is intended to convert an unstable phase $a U$ phase into a stable $\gamma U$ phase. In quenching experiments, the $U-10 Z r-1 N b, U-10 Z r-4 N b, U-10 Z r-7 N b$ ingot ingredients were fed into box that made of steel plate and then fed into a heating furnace and heated at $900{ }^{\circ} \mathrm{C}$ and held for 2 hours for then cooled rapidly in water. After quenched then subjected to phase testing and microstructure observation. The phase test is performed using X-ray diffraction (XRD) and the data is processed using High Score software, while the microstruture observation using optical microscope. Test results with $X R D$ showed that the U-10Zr-1Nb alloy before quenched consisted only of an aU phase, the $U-10 Z r-4 N b$ alloy consistof $23,1504 \%$ aU phases and $76,8495 \% \gamma U$ phases, while $U-10 Z r-7 N b$ consist of $34,1873 \% \alpha U$ phases and $65,8127 \% \gamma U$ phases. For U-10Zr-1Nb alloys after quenched consist of an $\alpha U$ phase, the $U-10 Z r-4 N b$ alloy consist of $44 \% \alpha U$ phases and $46 \% \gamma U$ phases, the $U-10 Z r-7 N b$ alloy consisted of $19 \% a U$ and $81 \%$ phases $\gamma U$. For $U-10 Z r-1 N b$ alloys after quenched consist of an $\alpha U$ phase, the U-10Zr-4Nb alloy consisted of $44,6711 \% \alpha U$ phases and $55,3289 \% \gamma U$ phase, the $U-10 Z r-7 N b$ alloy consist of $17,9918 \% \alpha U$ phases and of $82,0082 \% \gamma U$ phases. The results of the theoretical density analysis on the phases formed on U-10Zr-1Nb, $U-10 Z r-4 N b, U-10 Z r-7 N b$ alloys both before and after quenched were obtained that ingots of $U-10 Z r-1 N b, U-10 Z r-4 N b$ alloy $U-10 Z r-7 N b$ shows that the $\alpha U$ and $\gamma U$ phase densities decrease slightly if the $\mathrm{Nb}$ content is lower. Meanwhile, microstructure observation results showed that in the higher of $\mathrm{Zr}$ content ( $7 \% \mathrm{Nb}$ ) will formed smaller grains (fine) after quenching. It can be concluded that the quenching process of U-10Zr-1Nb, U-10Zr-4Nb and U-10Zr-7Nb alloys will change the phase that is from the $\alpha \cup$ phase to $\gamma \cup$ and the change the microstructure formed. The microstructural changes show that in the higher $\mathrm{Nb}$ content, the grains that are formed become more fine.

Keywords: microstructure, U-Zr-Nb, quenching, phase, density 


\section{PENDAHULUAN}

Salah satu tugas yang dilakukan oleh Pusat Teknologi Bahan Bakar Nuklir adalah mengembangkan bahan bakar untuk reaktor riset yang mempunyai densitas tinggi. Pengembangan bahan bakar berdensitas tinggi ini dimaksudkan untuk mengganti bahan bakar dari paduan uranium silisida $\left(\mathrm{U}_{3} \mathrm{Si}_{2} / \mathrm{Al}\right)$ yang sampai saat ini digunakan di RSG GAS di Serpong. Hal ini sejalan dengan program Reduced Enrichement for Research and Test Reactor (RERTR) yang dimotori oleh USA pada tahun 1978 yang mencanagkan penggunaan bahan bakar reaktor riset dari pemakaian uranium berpengkayaan tinggi (HEU) menjadi berpengkayaan rendah $<20 \%$ (LEU)[1]. Penggantian bahan bakar uranium silisida karena bahan bakar tersebut selain sulit untuk memisahkan $\mathrm{Si}$ dari hasil fabrikasi juga mempunyai keterbatasan tingkat muat uraniumnya (TMU) yang hanya sekitar $4,8 \mathrm{gU} / \mathrm{cm}^{3}[2]$. Beberapa paduan uranium sedang dikembangkan untuk mengganti bahan bakar uranium silisida diantaranya adalah : U-Cr, U-Mo, U-Nb, U-Re, U-Ru, U-Ti, U-V dan U-Zr.

Bahan bakar paduan berbasis $\mathrm{U}-\mathrm{Zr}$ merupakan salah satu bahan yang dikembangkan sebagai bahan bakar alternatif untuk mengganti bahan bakar reaktor riset. Beberapa peneliti telah mengembangkan bahan bakar tersebut seperti A. Landa, P. Soderlind, P. E. A. Turchi yang telah mempelajari pembuatan bahan bakar U-Mo dan U-Zr[3]. Pembuatan bahan bakar U-Zr-Nb juga telah dicoba dibuat oleh peneliti Bruno dkk yang membuat serbuk paduan $\mathrm{U}-\mathrm{Zr}-\mathrm{Nb}$ yang dipasivasi menggunakan teknik hidridingdehidriding[4]. Masrukan,dkk telah melakukan pengembangan bahan bakar dari paduan $\mathrm{U}-\mathrm{Zr}$ dimulai dari pembuatan ingot $\mathrm{U}-\mathrm{Zr}$, heat treatment, pembuatan serbuk hingga pembuatan Pelat Elemen Bakar (PEB) mini[5]. Paduan U-Zr pada temperatur kamar didominasi oleh fasa alpha ( $\alpha \mathrm{U})$ dan sisanya $\delta 1$ (UZr2), dimana pada kondisi tersebut paduan $\mathrm{U}-\mathrm{Zr}$ tidak stabil karena dapat mengalami swelling pada saat diirradiasi. Untuk membuat bahan bakar tersebut menjadi stabil maka paduan $\mathrm{U}-\mathrm{Zr}$ tersebut harus diubah menjadi fasa gamma $(\gamma \mathrm{U})$ yang lebih stabil. Perubahan dari fasa $\alpha U$ menjadi fasa $\gamma \cup$ dapat dilakukan dengan cara menambahkan unsur logam kedalam paduan U-Zr sehingga memperluas daerah fasa $\gamma U$. Unsur logam yang ditambahkan ke dalam paduan $\mathrm{U}-\mathrm{Zr}$ akan masuk baik secara substitusi atau interstisi ke dalam paduan $\mathrm{U}-\mathrm{Zr}$ dan akan masuk ke dalam fasa aU sehingga struktur fasa aU berubah. Unsur logam yang dapat ditambahkan untuk memperluas fasa gamma diantaranya adalah logam $\mathrm{Nb}, \mathrm{Mo}, \mathrm{Zr}$, Ti, Si[6,7]. Selain menambahkan unsur logam ke dalam paduan $\mathrm{U}-\mathrm{Zr}$, perubahan dari fasa $\alpha \mathrm{U}$ menjadi fasa $\gamma \mathrm{U}$ dapat pula dilakukan dengan cara perlakuan panas (heat treatment) yaitu quenching. Dalam penelitian ini dilakukan proses quenching terhadap paduan $\mathrm{U}-\mathrm{Zr}-\mathrm{Nb}$ dengan tujuan untuk mendapatkan fasa $\gamma \mathrm{U}$. Proses perlakuan panas quenching selain dapat mengubah fasa juga dapat merubah mikrostruktur dan sifat mekanik dari paduan tersebut.

Perlakuan panas (heat treatment) adalah salah satu proses untuk mengubah struktur logam dengan jalan memanaskan specimen di dalam tungku pada temperatur rekristalisasi selama periode waktu tertentu kemudian didinginkan pada media pendingin seperti udara, air, air garam, oli dan solar yang masing-masing mempunyai kerapatan pendinginan yang berbeda-beda. Sifat-sifat logam yang terutama sifat mekanik yang sangat dipengaruhi oleh mikrostrukturlogam disamping posisi kimianya. Dengan adanya pemanasan atau pendinginan dengan kecepatan tertentu maka bahan-bahan logam dan paduannya memperlihatkan perubahan strukturnya. Perlakuan panas adalah proses kombinasi antara proses pemanasan atau pendinginan dari suatu logam atau paduannya dalam keadaan padat untuk mendapatkan sifat-sifat tertentu. Untuk mendapatkan kondisi tersebut maka 
kecepatan pendinginan dan batas temperatur sangat menentukan. Ada empat macam perlakuan panas yaitu: (a). quenching, (b). annealing, (c). normalizing, dan (d). tempering[8,9].

\section{a. Proses quenching}

Pada dasarnya adalah proses pendinginan cepat yang dilakukan pada logam yang telah dipanaskan diatas temperatur kritisnya. Temperatur kritis besarnya adalah setengah dari titik cairnya dalam satuan derajat Kelvin (K). Pada proses quenching yang dilakukan terhadap paduan U-Zr-Nb dengan cara memanaskan daerah satu fasa yakni fasa $\gamma U$ dan ditahan untuk waktu tertentu kemudian didinginkan cepat sehingga unsur $\mathrm{Zr}$ dan $\mathrm{Nb}$ yang larut padat dalam logam $U$ akan terjebak tidak sempat keluar dan kembali menjadi fasa $a U$ dan $\delta 1$ akan tetapi terperangkap dalam fasa $\gamma \mathrm{U}$. Oleh karena itu proses quenching ini akan mengubah paduan U-Zr yang semula berfasa $\alpha U$ dan $\delta 1$ menjadi fasa $\gamma U$. Selain itu proses quenching tersebut akan membuat paduan $\mathrm{U}-\mathrm{Zr}-\mathrm{Nb}$ menjadi lebih keras.

\section{b. Pada proses tempering}

Proses ini biasanya merupakan lanjutan dari proses quenching dan bertujuan untuk mengurangi kegetasan material hasil quenching. Proses ini dilakukan dengan memanaskan material yang sudah diquenching pada temperatur di bawah temperatur kritisnya selama rentang waktu tertentu dan kemudian didinginkan secara perlahan. Dengan proses ini, keuletan logam/material dapat ditingkatkan tetapi kekerasan dan kekuatanya akan menurun. Proses temper dimaksudkan untuk memperoleh kombinasi antara kekuatan, keuletan dan ketangguhan yang tinggi

\section{c. Annealing}

Proses ini merupakan kebalikan proses quenching dan tempering. Dilakukan dengan memanaskan logam/material diatas temperatur kritisnya, kemudian didinginkan secara perlahan-lahan. Hasil dari proses ini adalah logam/material dengan sifat yang sama dengan sebelum dilakukan pengerasan (lunak).

\section{d. Normalizing}

Pada dasarnya normalizing ini sama dengan annealing. Perbedaannya terletak pada waktu pemanasan yang lebih pendek dan laju pendinginan yang lebih cepat. Hasilnya adalah logam/material yang mempunyai sifat lebih kuat dan lebih keras dari logam/material yang di-anneal secara penuh tetapi lebih mendekati sifat kondisi yang di-anneal daripada dengan yang ditemper.

Pada penelitian ini dilakukan proses quenching dari paduan U-Zr-Nb dengan cara memanaskan pada temperatur $900{ }^{\circ} \mathrm{C}$ dan ditahan selama 2 jam kemudian didinginkan cepat dengan menggunakan pendingin air. Pemanasan pada temperatur $900{ }^{\circ} \mathrm{C}$ dipilih karena pada temperatur tersebut paduan U-Zr-Nb berada pada daerah satu fasa yaitu $\gamma \mathrm{U}$, sedangkan penahanan selama 2 jam agar unsur-unsur yang larut menjadi satu fasa $\gamma \mathrm{U}$ dapat larut secara sempurna dan homogen. Hasil quenching selanjutnya dikenai pengujian fasa dan mikrostruktur yang terjadi.

\section{METODOLOGI}

Paduan U-Zr-Nb dibuat dengan cara melebur logam $\mathrm{U}, \mathrm{Zr}$ dan $\mathrm{Nb}$ di dalam tungku peleburan busur listrik yang beroperasi pada arus $125 \mathrm{~A}$ dan dilengkapi dengan sistem pendingin air. Pembuatan ingot dilakukan dengan memvariasikan logam $\mathrm{Nb}$ sedangkan logam $\mathrm{Zr}$ tetap sebesar 10 \%berat dan logam $U$ menyesuaikan. Logam $\mathrm{Nb}$ yang divariasikan berturut-turut sebesar $1 \%, 4 \%$ dan $7 \%$ (U-10Zr-1Nb, U-10Zr-4Nb, U-10Zr-7Nb). Ingot U-10Zr-1 Nb, U-10Zr-4Nb, U-10Zr-7Nb yang dibuat berbentuk setengah lingkaran dengan diameter lingkaran $15 \mathrm{~mm}$ dan ketebalan $5 \mathrm{~mm}$ selanjutnya dimasukkan ke 
dalam wadah berupa ampul yang terbuat dari pelat baja dengan ketebalan $1 \mathrm{~mm}$ dan ditutup rapat sehingga udara tidak bisa masuk ke dalam ampul. Wadah atau ampul yang beriasi ingot $\mathrm{U}-10 \mathrm{Zr}-1 \mathrm{Nb}, \mathrm{U}-10 \mathrm{Zr}-4 \mathrm{Nb}$, dan $\mathrm{U}-10 \mathrm{Zr}-7 \mathrm{Nb}$ dimasukkan ke dalam tungku pemanas untuk dikenai pemanasan pada temperatur $900{ }^{\circ} \mathrm{C}$ dan ditahan selama 2 jam. Setelah proses pemanasan selesai, wadah yang berisi ingot $\mathrm{U}-10 \mathrm{Zr}-1 \mathrm{Nb}$, $\mathrm{U}-10 \mathrm{Zr}-4 \mathrm{Nb}, \mathrm{U}-10 \mathrm{Zr}-7 \mathrm{Nb}$ dimasukkan ke dalam ember yang berisi air (proses quenching). Setelah proses quenching selesai, ingot $\mathrm{U}-10 \mathrm{Zr}-1 \mathrm{Nb}, \mathrm{U}-10 \mathrm{Zr}-4 \mathrm{Nb}$, $\mathrm{U}-10 \mathrm{Zr}-7 \mathrm{Nb}$ dikeluarkan dari dalam ampul untuk dilakukan proses pengujian lebih lanjut yaitu analisis mikrostruktur menggunakan mikroskop optik dan fasa menggunakan difraksi sinar-X (XRD) yang hasilnya dianalisis dengan metode Rietveld menggunakan software Hight Score. Sebelum dilakukan pengujian mikrostruktur dan XRD, ingot U-10Zr-1 Nb, U-10Zr-4Nb, $\mathrm{U}-10 \mathrm{Zr}-7 \mathrm{Nb}$ dihaluskan dengan cara digerinda pada salah satu permukaannya dan dilanjutkan dengan pemolesan dengan menggunakan pasta alumina. Dalam melakukan pemeriksaan mikrostruktur permukaan sampel yang telah dipoles kemudian dietsa menggunakan campuran larutan $\mathrm{HNO}_{3}, \mathrm{HF}$ dan $\mathrm{H}_{2} \mathrm{O}$. Skema jalannya proses quenching digambarkan pada Gambar 1.

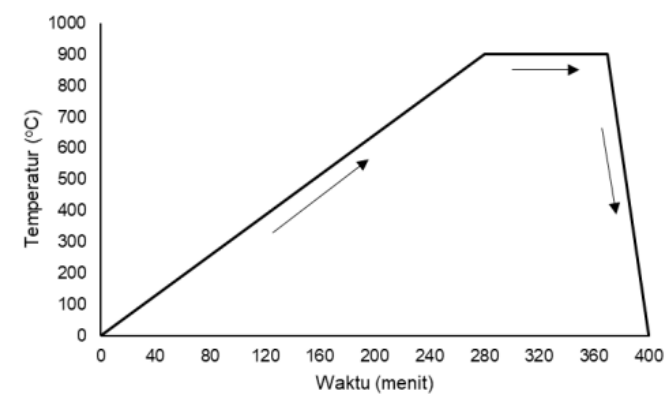

Gambar 1. Skema proses quenching $\mathrm{U}-\mathrm{Zr}-\mathrm{Nb}$

\section{HASIL DAN PEMBAHASAN}

\section{a. Analisis fasa}

Gambar 2, 3, 4 dan 5 merupakan hasil analisis menggunakan XRD ingot paduan U-10Zr-1 Nb, U-10Zr-4Nb,
$\mathrm{U}-10 \mathrm{Zr}-7 \mathrm{Nb}$ sebelum diquenching dapat dilihat bahwa pada kadar $\mathrm{Nb}$ yang semakin tinggi maka fasa gamma $(\gamma \mathrm{U})$ yang terbentuk akan semakin tinggi sedangkan fasa alpha $(\alpha \mathrm{U})$ semakin berkurang, bahkan pada kandungan $\mathrm{Nb}$ sebesar $1 \%$ hanya terdapat fasa aU. Kondisi ini ditunjukkan oleh intensitas sinar yang muncul pada sudut $2 \theta$ yang ada. Pada Gambar 5 terlihat lebih jelas komposisi fasa dimana pada U-10Zr-1Nb hanya terdiri dari fasa $\alpha \mathrm{U}$, pada paduan $\mathrm{U}-10 \mathrm{Zr}-4 \mathrm{Nb}$ terdiri dari fasa $\mathrm{aU}$ sebesar $2,1504 \%$ dan fasa $\gamma U$ sebesar $7,8496 \%$, sedangkan pada U-10Zr-7Nb terdiri dari fasa aU sebesar $34,1873 \%$ dan fasa $\gamma \mathrm{U}$ sebesar $65,8127 \%$. Hal ini menunjukkan bahwa penambahan unsur $\mathrm{Nb}$ akan memperluas daerah fasa $\gamma \mathrm{U}$ dan penambahan unsur $\mathrm{Nb}$ yang semakin tinggi maka fasa $\gamma U$ yang terbentuk akan semakin tinggi pula. Masuknya unsur Nb baik secara substitusi akan merubah struktur kristal dari fasa $a \mathrm{U}$ yang semula orthorombic menjadi berstruktur kristal body centre cubic (bcc) dan berfasa $\gamma \mathrm{U}$. Di dalam bahan bakar nuklir khususnya untuk reaktor riset, dibutuhkan kondisi bahan bakar yang stabil. Bahan bakar paduan uranium akan stabil apabila berada dalam kondisi fasa $\gamma \mathrm{U}$. Gambar 2 menunjukkan bahwa fasa $\alpha U$ pada U- $6 \mathrm{Zr}-1 \mathrm{Nb}$ muncul pada sudut $2 \theta$ sebesar 34,8886; 35.5847; 35.5847; 39.436 dengan hkl masing-masing (110), (021), (002), (111) dan intensitas sebesar 53\%, $100 \%$, $47,16 \%$ dan $67,97 \%$. Pada paduan $\mathrm{U}-6 \mathrm{Zr}-4 \mathrm{Nb}$, terdapat dua fasa yakni fasa $a \mathrm{U}$ dan $\gamma \mathrm{U}$ seperti ditunjukkan pada Gambar 3. Gambar 3 memperlihatkan bahwa fasa $\alpha \mathrm{U}$ muncul pada sudut $2 \theta$ sebesar 34,7499 ; 35,7233; 35,9263; dan 39,2881 dengan hkl masing-masing pada (110), (021), (002), dan (111) serta intensitas sebesar 20,25\%; $26,95 \% ; 14,53 \%$ dan $15,5 \%$. Fasa $\gamma U$ pada paduan U-6Zr-4Nb muncul pada sudut $2 \theta$ sebesar 35,$8873 ; 36,2038 ; 64,7835$; dan 65,40 dengan $\mathrm{hkl}$ masing-masing (020), (111), (131), (022) serta intensitas sinar masing-masing sebesar 54,58 \%; 54,58\%; $13,58 \%$ dan $5,69 \%$. Sama halnya pada paduan U-10Zr-4Nb, pada paduan U-10Zr-7Nb seperti ditunjukkan pada 
Gambar 4 juga terdapat dua fasa yakni fasa $\alpha U$ dan $\gamma \mathrm{U}$. Fasa $\alpha \mathrm{U}$ muncul pada sudut $2 \theta$ sebesar 35,8873; 36,20,38; 64,7835; dan 65,4003 dengan hkl masing-masing (020), (111), (131), (022) dengan intensitas sinar masing-masing sebesar 54,58\%; $100 \%$; $13,58 \%$ dan $5,69 \%$. Apabila diamati dari komposisi fasa yang ada seperti pada Gambar 5 dapat dilihat bahwa pada U-10Zr$1 \mathrm{Nb}$ hanya terdiri dari fasa $\mathrm{aU}$, pada paduan U-10-4Nb terdiri dari fasa aU sebesar $23,15042 \%$ dan fasa $\gamma \mathrm{U}$ sebesar $76,8495 \%$ dan pada $\mathrm{U}-10 \mathrm{Zr}-7 \mathrm{Nb}$ terdiri dari fasa $a \mathrm{U}$ sebesar $34,1873 \%$ dan fasa $\gamma U$ sebesar $65,8127 \%$.

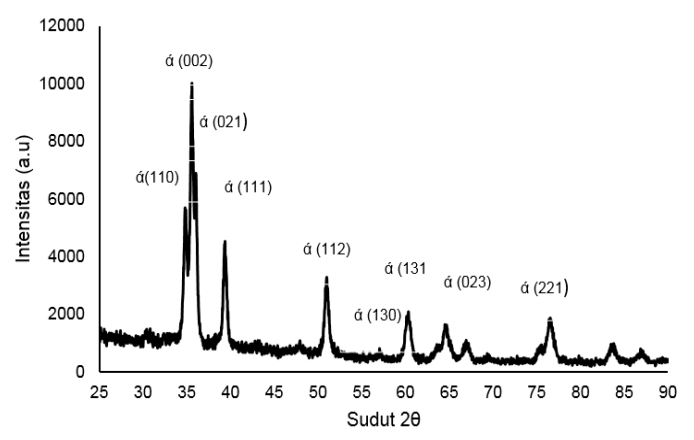

Gambar 2. Pola difraksi Ingot U-10Zr-1Nb sebelum diquenching

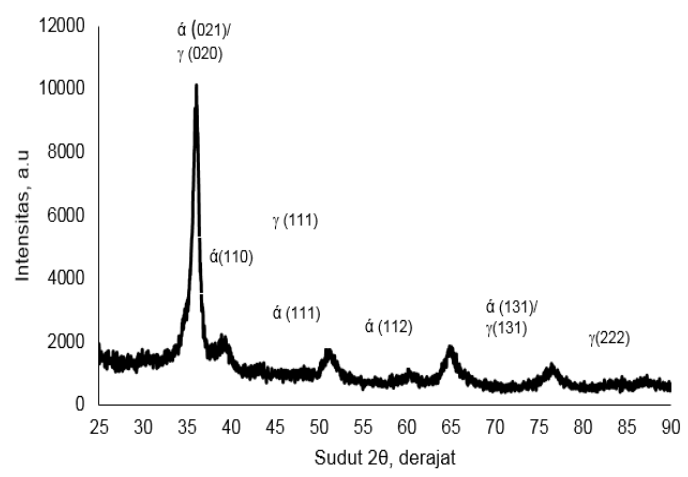

Gambar 3. Pola difraksi Ingot U-10Zr-4Nb sebelum diquenching

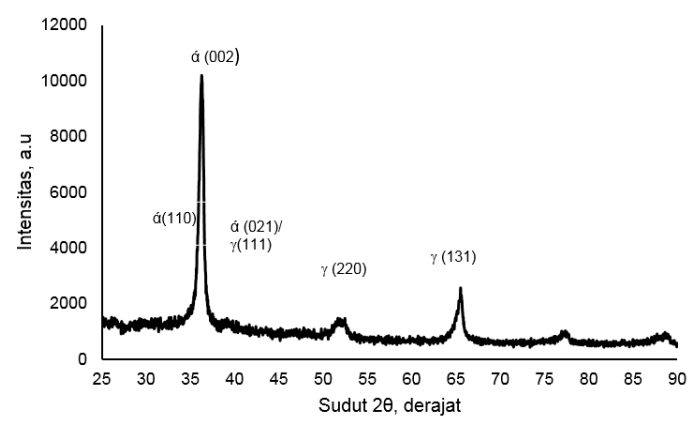

Gambar 4. Pola difraksi ingot U-10Zr-7Nb sebelum diquenching

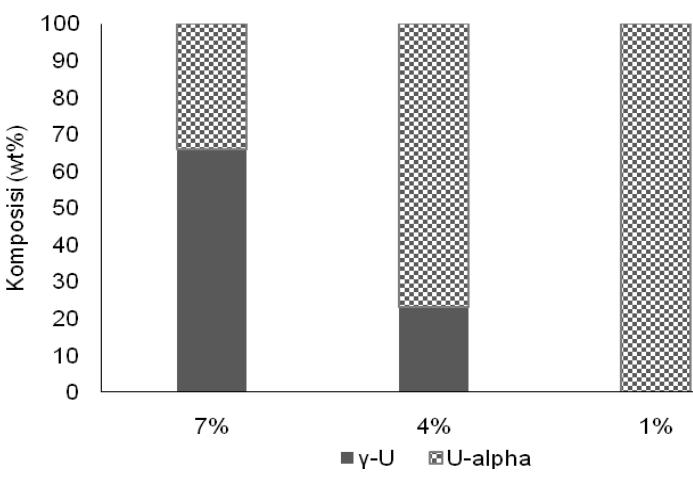

Gambar 5. Grafik batang komposisi (\%) berat terhadap fasa yang terbentuk sebelum diquenching

Hasil analisis pada paduan U-10Zr-1 Nb, U-10Zr-4Nb, U-10Zr-7Nb pasca proses quenching ditampilkan pada Gambar 6, 7, 8 dan 9. Gambar 6 yang merupakan hasil pengujian XRD pada paduan U-10Zr-1 Nb menunjukkan bahwa pada penambahan $1 \% \mathrm{Nb}$ yang dikenai proses quenching hanya tedapat fasa aU. Dengan demikian maka penambahan unsur $\mathrm{Nb} 1 \%$ dan dikenai proses quenching ternyata tidak membe-rikan pengaruh pada perubahan fasa. Fasa $\mathrm{aU}$ muncul pada sudut $2 \theta$ sebesar 34,$88 ; 35,58 ; 36,15$; 39,46 ; dan $51,3 \%$ dengan hkl masingmasing sebesar 110, 021, 002, 111, dan 112 dengan intensitas sinar masing-masing sebesar 53,8\%; $100 \%, 47,16 \% ; 67,97 \%$ dan $24,3 \%$. Pada paduan U-10Zr-4Nb setelah diquenching seperti ditunjukkan pada Gambar 7 terlihat bahwa paduan tersebut terdiri dari dua fasa yakni fasa $a U$ dan fasa $\gamma \mathrm{U}$. Demikian pula untuk paduan $\mathrm{U}-10 \mathrm{Zr}-7 \mathrm{Nb}$ dengan penambahan $\mathrm{Nb}$ sebesar $7 \%$ terlihat fasa $\gamma \cup$ yang semakin tinggi sedangkan fasa aU semakin berkurang. Keadaan ini dapat dilihat dari intensitas sinar yang muncul pada masingmasing fasa. Melalui pengolah data software High Score diperoleh komposisi masingmasing $g$ fasa $\alpha U$ dan $\gamma \mathrm{U}$ seperti tertera pada Gambar 9. Komposisi masing-masing fasa pada Gambar 9 adalah untuk paduan $\mathrm{U}-10 \mathrm{Zr}-1 \mathrm{Nb}$ semua fasa $a \mathrm{U}$, paduan $\mathrm{U}-10 \mathrm{Zr}-4 \mathrm{Nb}$ fasa $a \mathrm{U}$ sebesar $44,6711 \%$ dan fasa $\gamma U$ sebesar $55,3298 \%$, paduan $\mathrm{U}-10 \mathrm{Zr}-7 \mathrm{Nb}$ mempunyai kandungan fasa $\alpha \mathrm{U}$ sebesar $17,9918 \%$ dan fasa $\gamma U$ sebesar $82,0082 \%$. Fasa $\alpha U$ muncul pada sudut $2 \theta$ 
sebesar 34,19; 35,76; 36,35; 39,35; 51,21; dan 60,40 dengan hkl masing-masing sebesar 110, 021, 002, 111, 112 dan 131 dengan intensitas sinar masing-masing sebesar $\quad 38,03 \%$; $50,9 \% ; \quad 26,48 \%$; $28,45 \% ; 19,855$; dan $14,17 \%$. Untuk fasa $\gamma \mathrm{U}$ pada paduan $\mathrm{U}-10 \mathrm{Zr}-4 \mathrm{Nb}$ hasil quenching muncul pada sudut $2 \theta$ masingmasing sebesar 31,$35 ; 35,96 ; 36,24$; dan 64,67 dengan hkl masing-masing sebesar $011,020,111,220$ dan 131 dengan intensitas sinar masing-masing sebesar $73,71 \%$; $59,94 \% ; \quad 100 \% ; \quad 4,34 \%$; dan $5,49 \%$. Pada paduan U-10Zr-7Nb seperti pada paduan $\mathrm{U}-10 \mathrm{Zr}-4 \mathrm{Nb}$ yang terdiri dari dua fasa yakni fasa $a U$ dan $\gamma \mathrm{U}$. Fasa $a U$ muncul pada sudut $2 \theta 34,8168$; 35,8425; 36,413 ; 39,427; 60,441 dengan hkl masingmasing 110, 021, 002, 111, 112 dan intensitas sinar masing-masing sebesar $8.98 \%$; $12.02 \%$; $6.27 \%$; $7.36 \%$; $6.6 \%$. Sementara itu, fasa $\gamma \mathrm{U}$ muncul pada sudut $2 \theta$ berturut-turut sebesar 36,$1112 ; 36,315$; 52,$17 ; 52,2481 ; 65,129$ dengan hkli berturutturut sebear 020, 111, 220, 131, 022 dna intensitas sinar masing-masing sebesar 53,51; 100; 11,06; 15.6; 6.65. Hasil percobaan ini bersesuaian dengan hasil percobaan yang diperoleh oleh Rafael Witter dkk, dimana dari proses quenching paduan $\mathrm{U}-\mathrm{Zr}-\mathrm{Nb}$ diperoleh fasa $a \mathrm{U}, \gamma \mathrm{U}$ dan $\delta$ UZr2[10,11]. Apabila dilihat dari proses quenching kemudian dibandingkan antara paduan $\mathrm{U}-\mathrm{Zr}-\mathrm{Nb}$ yang belum diquenching dengan yang telah diquenching maka dapat diketahui bahwa pada penambahan $\mathrm{Zr}$ yang lebih tinggi $(7 \%)$ terjadi perubahan fasa yang signifikan. Pada U-10Zr-7Nb yang tidak diquenching mempunyai kandungan fasa $\gamma \mathrm{U}$ sebesar $66 \%$ dan $\alpha \mathrm{U}$ sebesar $34 \%$ maka setelah diquenching fasa $\gamma \mathrm{U}$ menjadi sebesar $82,008 \%$ dan fasa aU sebesar $17,992 \%$. Hal ini disebabkan pada saat proses quenching, unsur-unsur yang terlarut pada pemanasan temperatur tinggi dan kemudian didinginkan dengan cepat maka pada pendingina cepat unsur yang terlarut tidak sempat kembali ke fasa semula dan tertahan dalam fasa $\gamma \mathrm{U}$.

Analisis fasa yang terbentuk antara paduan U-10Zr-1Nb, U-10Zr-4Nb, U-10Zr-
$7 \mathrm{Nb}$ sebelum dan sesudah diquenching dapat dikatakan bahwa pada proses quenching akan menghasilkan fasa $\gamma \mathrm{U}$ yang lebih besar apabila kandungan $\mathrm{Zr}$ lebih tinggi.

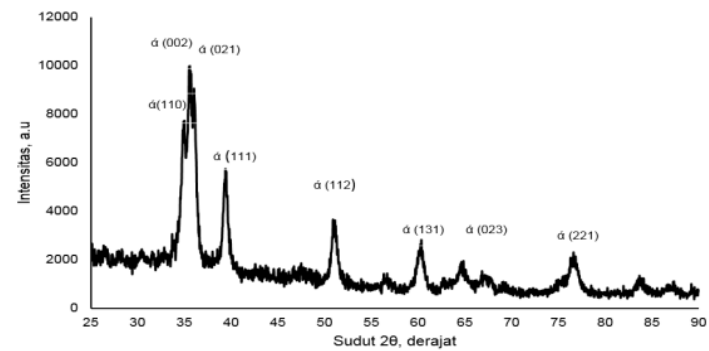

Gambar 6. Pola difraksi U-10Zr-1 Nb diquenching

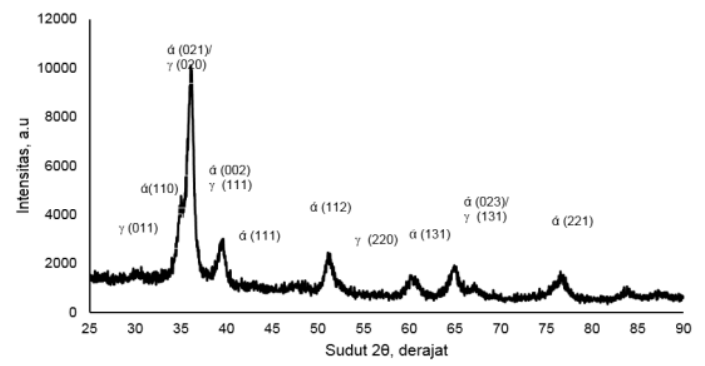

Gambar 7. Pola difraksi U-10Zr-4Nb setelah diquenching

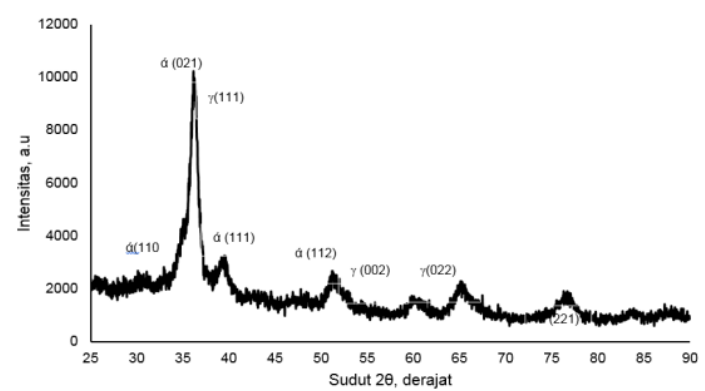

Gambar 8. Pola difraksi U-10Zr-7Nb setelah diquenching

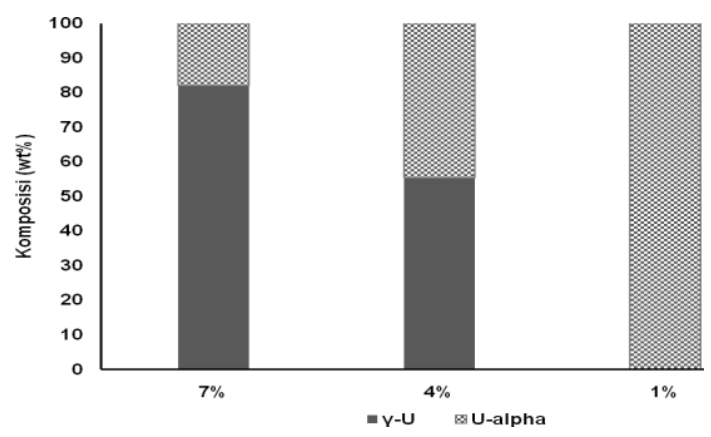

Gambar 9. Grafik batang komposisi (\%) berat terhadap fasa setelah quenching 


\section{b. Analisis densitas}

Hasil analisis densitas teoritis fasa yang terbentuk pada paduan $\mathrm{U}-10 \mathrm{Zr}-1 \mathrm{Nb}$, $\mathrm{U}-10 \mathrm{Zr}-4 \mathrm{Nb}, \quad \mathrm{U}-10 \mathrm{Zr}-7 \mathrm{Nb}$ baik sebelum diquenching maupun setelah diquenching yang diperoleh melalui perhitungan menggunakan software High Score ditampilkan pada Gambar 10 dan Gambar 11. Hasil densitas yang diperoleh pada ingot paduan U-10Zr-1Nb, U-10Zr-4Nb, $\mathrm{U}-10 \mathrm{Zr}-7 \mathrm{Nb}$ sebelum diquenching menunjukkan bahwa densitas fasa $\alpha \mathrm{U}$ dan fasa $\gamma U$ mengalami penurunan sedikit apabila kandungan $\mathrm{Nb}$ semakin rendah atau dapat dikatakan semakin tinggi kadar $\mathrm{Nb}$ maka semakin tinggi densitasnya. Sebagai contoh pada $7 \% \mathrm{Nb}(\mathrm{U}-10 \mathrm{Zr}-7 \mathrm{Nb})$ fasa aUdan fasa $\gamma \mathrm{U}$ masing-masing mempunyai densitas sebesar 19,3 g/ $/ \mathrm{cm}^{3}$ dan 16,05 $\mathrm{g} / \mathrm{cm}^{3}$ lebih tinggi dibandingkan padapaduan $\mathrm{U}-10 \mathrm{Zr}-4 \mathrm{Nb}$ yang masing-masing fasa $\alpha \mathrm{U}$ dan fasa $\gamma U$ mempunyai densitas sebesar $19,05 \mathrm{~g} / \mathrm{cm}^{3}$ dan $15,83 \mathrm{~g} / \mathrm{cm}^{3}$. Pada kandungan $1 \% \quad \mathrm{Nb} \quad(\mathrm{U}-10 \mathrm{Zr}-1 \mathrm{Nb})$ yang hanya terdiri dari fasa aU maka nilai densitas hanya dari fasa $a U$.

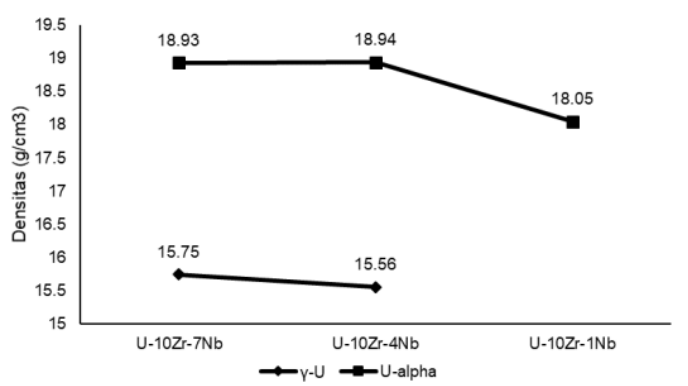

Gambar 10. Pengaruh kandungan Nb terhadap densitas fasa sebelum diquenching

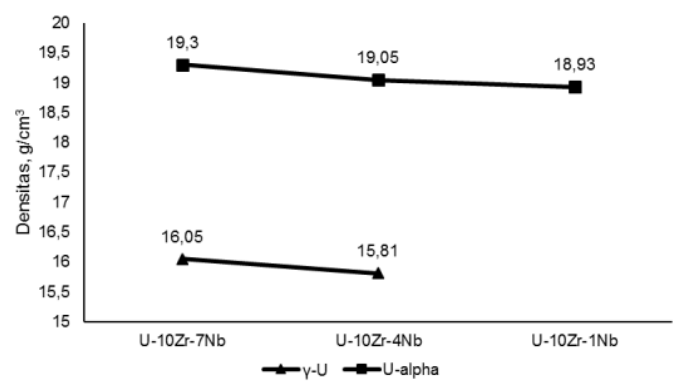

Gambar 11. Pengaruh kandungan $\mathrm{Nb}$ terhadap densitas fasa setelah diquenching
Gambar 11 yang memperlihatkan hasil perhitungan densitas ingot paduan $\mathrm{U}-10 \mathrm{Zr}-1 \mathrm{Nb}, \mathrm{U}-10 \mathrm{Zr}-4 \mathrm{Nb}$, dan U-10Zr-7Nb terlihat bahwa terjadi penurunan nilai densitas fasa aUdan fasa $\gamma \mathrm{U}$ apabila kandungan $\mathrm{Nb}$ turun seperti yang dialami pada fenomena pada Gambar 10 yang tidak diquenching. Pada kandungan $\mathrm{Nb}$ sebesar $1 \% \mathrm{Nb}(\mathrm{U}-10 \mathrm{Zr}-1 \mathrm{Nb})$ yang hanya terdiri dari fasa aU maka nilai densitas hanya dari fasa $a U$.

Apabila dibandingkan antara hasil sebelum dikenakan proses quenching dan setelah diquenching terlihat bahwa densitas total (fasa $a U$ dan fasa $\gamma \mathrm{U}$ ) pada tiap komposisi memperlihatkan bahwa sebelum diquenching mempunyai densitas yang lebih tinggi. Sebagai contoh pada U-10Zr-7Nb, densitas total sebesar $17,675 \mathrm{~g} / \mathrm{cm}^{3}$ sedangkan setelah diquenching mempunyai densitas sebesar $17,34 \mathrm{~g} / \mathrm{cm}^{3}$, dimana hal ini disebabkan karena setelah diquenching paduan $\mathrm{U}-10 \mathrm{Zr}-7 \mathrm{Nb}$ mempunyai fasa $\gamma \mathrm{U}$ yang lebih tinggi. Oleh karena fasa $\gamma U$ mempunyai densitas yang lebih rendah dari pada fasa aU sehingga densitas total menjadi lebih rendah pula.

\section{c. Analisis mikrostruktur}

Hasil pengujian mikrostruktur paduan U-10Zr-1Nb, U-10Zr-4Nb, dan U-10Zr-7Nb setelah diquenching ditampilkan pada Gambar 12, Gambar 13 dan Gambar 14. Mengacu pada Gambar 12, Gambar 13 dan Gambar 14 pada paduan U-10Zr-1 Nb mempunyai bentuk butir lebih besar (kasar) dibandingkan paduan $\mathrm{U}-10 \mathrm{Zr}-4 \mathrm{Nb}$, dan $\mathrm{U}-10 \mathrm{Zr}-7 \mathrm{Nb}$. Dengan lain kata bahwa pada kandungan $\mathrm{Zr}$ yang semakin tinggi $(7 \% \mathrm{Nb})$ terbentuk butir lebih kecil (halus) setelah mengalami quenching. Proses quenching selain mengubah fasa dari fasa $\alpha U$ dan $\delta U$ menjadi fasa $\gamma U$ juga akan mempengaruhi pembentukan butir. Pada kandungan $\mathrm{Nb}$ yang semakin tinggi maka pada saat pendinginan cepat adanya unsur $\mathrm{Nb}$ yang merupakan inti terjadinya butir akan membentuk butir yang semakin banyak tetapi butir yang terbentuk semakin halus. 
Pada kandungan $\mathrm{Zr}$ yang semakin tinggi juga akan membentuk fasa $\gamma \mathrm{U}$ yang semakin tinggi sedangkan fasa $a U$ menjadi semakin berkurang karena sebagian akan membentuk fasa $\gamma \cup$ setelah diquenching.

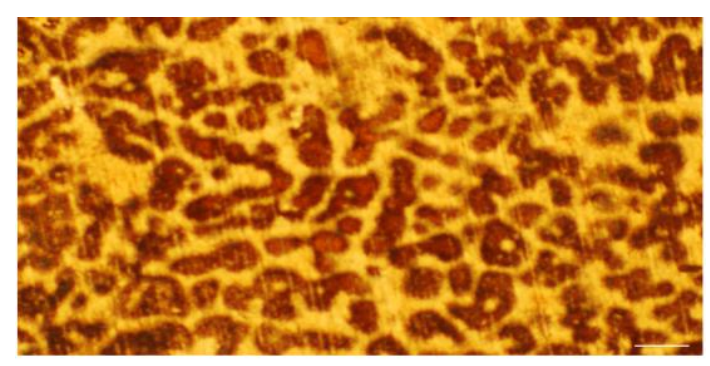

$12,5 \mu \mathrm{m}$

Gambar 12. Mikrostruktur ingot paduan $\mathrm{U}-10 \mathrm{Zr}-1 \mathrm{Nb}$ hasil quenching

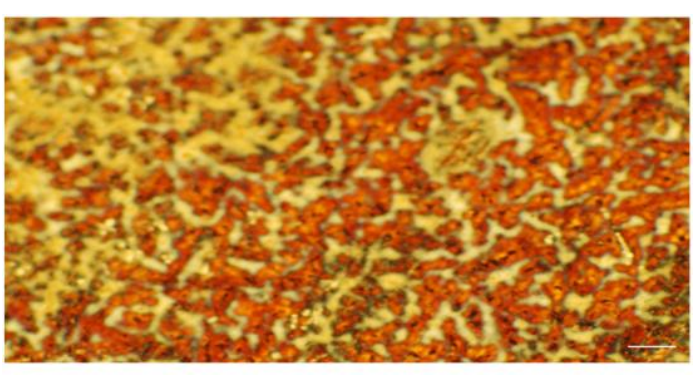

$12,5 \mu \mathrm{m}$

Gambar 13. Mikrostruktur ingot paduan $\mathrm{U}-10 \mathrm{Zr}-1 \mathrm{Nb}$ hasil quenching

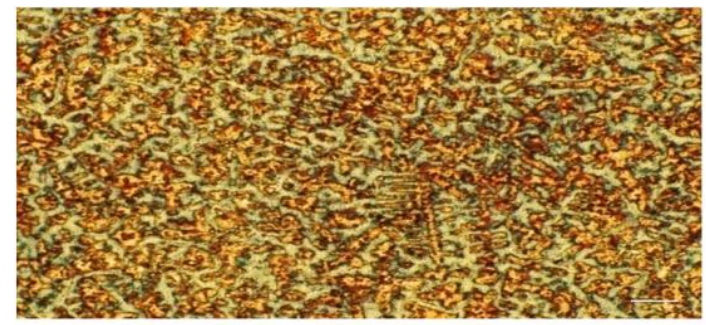

$12,5 \mu \mathrm{m}$

Gambar 14. Mikrostruktur ingot paduan $\mathrm{U}-10 \mathrm{Zr}-7 \mathrm{Nb}$ hasil quenching

\section{SIMPULAN}

Proses quenching yang dilakukan mampu mengubah fasa aU menjadi fasa $\gamma$-U untuk paduan U-10Zr-4Nb (4\% $\%$ Nb) dan U-10Zr-7Nb $(7 \% \mathrm{Nb})$ sedangkan $\mathrm{U}-10 \mathrm{Zr}-1 \mathrm{Nb}(1 \% \mathrm{Nb})$ tidak berubah. Dari perhitungan densitas diperoleh nilai densitas fasa $\alpha-U$ dan fasa $\gamma U$ akan turun bila kandungan $\mathrm{Nb}$ semakin rendah, dan nilai densitas total (fasa $a U$ dan fasa $\gamma \mathrm{U}$ ) sebelum diquenching lebih tinggi daripada setelah diquenching. Hasil pengamatan mikrostruktur setelah diquenching menunjukkan bahwa semakin tinggi kandungan $\mathrm{Nb}$ di dalam paduan U-Zr- $\mathrm{Nb}$ maka semakin halus butir yang terbentuk.

\section{UCAPAN TERIMA KASIH}

Dalam kesempatan ini kami mengucapkan terima kasih kepada temanteman di BFBBN-PTBBN yang telah membantu pelaksanaan percobaan khususnya kepada bapak Yatno D.A dan bapak Slamet $P$ sehingga prcobaan ini selesai.

\section{DAFTAR PUSTAKA}

[1] Supardjo, "Pengembangan paduan uranium berbasis U-Mo sebagai kandidat bahan bakar nuklir untuk reaktor riset menggantikan bahan bakar dispersi $\mathrm{U}_{3} \mathrm{Si}_{2}$-Al," Prosiding Seminar Nasional Pengembangan Energi Nuklir IV, 2011, hal. 444.

[2] Supardjo, H. Suwarno dan A. Kadarjono, "Karakterisasi paduan U-7\%Mo dan U-7\%Mox\%Si ( $x=1,2$, dan $3 \%$ ) hasil proses peleburan dalam tungku busur listrik," Jurnal Daur Bahan Bakar Nuklir Urania", vol.15, no. 4, hal. 172, 2009.

[3] A. Landa, P. Soderlind, P.E.A. Turchi, "Density-Functional study of U-Mo and U-Zr alloys", Journal of Nuclear Materials, vol. 414, no. 2, pp. $132-$ 137, 2011.

[4] B.M. Aguiar, D.M. Braga, J.B. Paula, W. de Brito, "Methodology of $\mathrm{U}-\mathrm{Zr}-\mathrm{Nb}$ alloy powder passivation obtained by hydride-dehydride process," Proceeding of International Nuclear Atlantic Conference - INAC 2007, Santos, Brazil.

[5] Masrukan, "Pembuatan pelat elemen bakar mini U-6\%Zr/Al untuk bahan bakar reaktor riset", Prosiding Pertemuan dan Presentasi IImiah 
(PPIS) 2012, Badan Standarisasi Nasional (BSN).

[6] Supardjo, "Study of the change process as fuel U-Mo powder dispersion U-Mo/Al for a research reactor" Prosiding PPI-PDIPTNYogyakarta, 2007, Accelerator Center and Process Materials-BATAN

[7] Masrukan, M.H. Al Hasa, J.Setiawan, S. Pribadi, "Effect of $\mathrm{Nb}$ element content in $\mathrm{U}-\mathrm{Zr}$ alloy on hardness: microstructure and phase formation," Jurnal Daur Bahan Bakar Nuklir Urania", vol. 21, no. 2, 2015.

[8] R.W.D. Pais, A.M.M. dos Santos, F.S. Lameiras and W.B. Ferraz, "Isothermal phase transformation of $\mathrm{U}-\mathrm{Zr}-\mathrm{Nb}$ alloys for advanced nuclear fuels," Proceeding of Nuclear Technology Development Centre, Belo Horizonte, Brazil.

[9] A. Yuliyanto, "Studi pengaruh perlakuan panas terhadap struktur mikro dan sifat mekanis baja ASSAB $705 \mathrm{M}$ yang digunakan pada komponen stud pin winder," Skripsi, Jurusan Teknik Mesin, Fakultas Teknik, Universitas Muhammadiyah Surakarta, hal 5-6, 2015.

[10] A. Moore, "Atomistic Study Of The Structure, Thermodynamics, And Morphological Evolution Of Uranium Zirconium Alloys," A Dissertation Doctor of Philosophy in the School of Mechanical Engineering Georgia Institute of Technology, USA, pp.6769, 2016.

[11] C.L. Komar Varela, L.M. Gribaudo, R.O. Gonzalles, S.F. Arico, "Tranformation behavior of the $\gamma(\mathrm{U}-\mathrm{Zr}-\mathrm{Nb})$ phase under continues cooling conditions," Journal of Nuclear Materials, vol. 453, no. 1-3, pp. 124130, 2014. 